Energy Research Journal 1 (2): 152-157, 2010

ISSN 1949-0151

(C) 2010 Science Publications

\title{
Cost Comparisons in the Rice Disinfestations between Infrared Radiations Heating Application and Chemical Application
}

\author{
Withaya Insorn, Sukangkana Lee, Nalin Piantong and Adun Janyalertadun \\ Department of Industrial Engineering, Faculty of Engineering, \\ Ubon Ratchathani University, Ubonratchathani, Thailand 34190
}

\begin{abstract}
Problem statement: Rice is one of importance export goods especially Hom Mali Rice. Therefore, rice storage is very important. The main enemy of Hom Mali Rice is Rice Weevil. It is a small insect and grows fast with small amount of food eating. Its deteriorate rice by bite both internal and external rice kernel resulting in damage and loss of rice. However, its necessary to the study of cost in the rice disinfestations between the Infrared radiation heating application and chemical application in order to obtain information in decision making. Approach: The purpose of this research is to evaluate cost structure in the disinfestations of rice insect between chemical method and infrared radiation heating application. Methodology: (1) Data and information collected by surveying and rice milling enterprises from private in Surin province. The information studied were type of insects, rice storage method, organization and business method, cost structure and exportation system. (2) Cost analysis and rate of return. Results: The calculation of cost based on the large rice mill export factory in Surin province of Thailand. The cost structure of rice milling can be divided into 2 types: Fixed cost and variable cost which are equal to 5,385,256 baht ( $2 \%$ of total cost) and $274,922,345$ baht (98 \% of total cost), respectively. The rate of return in rice milling is 19,020 ton year ${ }^{-1}$. The income is from rice sale was approximately $284,349,000$ baht $(82.93 \%$ of total income) and from broken rice sale was approximately $30,812,400$ baht ( $8.99 \%$ of total income). The cost of disinfestations by infrared radiation heating application and chemical equal to 0.3096 and $0.3037 \mathrm{baht} \mathrm{kg}^{-1}$, respectively. Therefore, the nonchemical method increase total cost only by $1 \%$ or 112,218 baht. Conclusion: Major enemy of Hom Mali Rice during stock is rice weevil. The rice deteriorations caused by rice weevil such as dirty rice, powder dust, weight loss and bad taste. The economic expenses and involving cost in applying radiation heating and chemical were calculated and compared. The cost structure of rice milling business consist of 2 groups include fixed cost equal to 5,385,256 baht ( $2 \%$ of total cost) and variable cost equal to $274,922,345$ baht ( $98 \%$ of total cost). The rate of return in rice milling was 19,020 ton year $^{-1}$. The total cost of using infrared radiation heating application and chemical application equal to 0.3096 and 0.3037 bath $\mathrm{kg}^{-1}$, respectively. Therefore, the infrared method increase total cost by $1 \%$ or cost increase of 112,218 baht year $^{-1}$.
\end{abstract}

Keywords: Cost, infrared radiation, chemical, rice weevil

\section{INTRODUCTION}

Rice (Scientific name: Oryzae sativa L.) is an important plant for human for several year. The populations of more than half the world consume rice. Thailand has a reputation as an export rice country. The main planting area in Thailand is the northeast region. The mainly type of rice planted is Hom Mali Rice due to it well endurance to dry atmosphere, good price sale and widely marketing. The most popular
Hom Mali planted in the northeast region is Hom Mali Rice 105 which is a high quality rice and unique fragrance. The major planting provinces such as Mahasarakham, Roi-et, Yaksothon, Surin and Sesakhet province (Buanuan, 2009).

Rice is one of an important export goods especially Hom Mali Rice. The quantity and value of the Hom Mali Rice class 2(100\%) reported by the Thai rice export association between year 2005-2008 is shown in Table 1 . Also major countries of exportation are listed in Table 2.

Corresponding Author: Withaya Insorn, Department of Industrial Engineering, Faculty of Engineering, Ubon RatchathaniUniversity, Ubonratchathani, Thailand 34190 
Energy Rec. J. 1 (2): 152-157, 2010

Table 1: The export of Hom Mali rice class 2 (100\%)

\begin{tabular}{lllll}
\hline Year & 2005 & 2006 & 2007 & 2008 \\
\hline $\begin{array}{l}\text { Quantity of export } \\
\text { (ton million) }\end{array}$ & 1.15 & 1.32 & 1.42 & 1.20 \\
$\begin{array}{l}\text { Total of value } \\
\text { (million baht) }\end{array}$ & 20,572 & 25,038 & 27,056 & 33,298 \\
$\begin{array}{l}\text { Average value ton } \\
\text { (baht } \text { ton }^{-1} \text { ) }\end{array}$ & 17,928 & 18,961 & 19,077 & 27,710 \\
\hline
\end{tabular}

Table 2: The major exportation countries of Hom Mali rice 100\% class 2 from Thailand

\begin{tabular}{|c|c|c|c|c|}
\hline \multirow[b]{2}{*}{ Country } & \multicolumn{4}{|l|}{ Unit (ton) } \\
\hline & 2548 & 2549 & 2550 & $2551 *$ \\
\hline America & 263,648 & 299,732 & 298,326 & 274,400 \\
\hline China & 244,678 & 270,125 & 185,316 & 83,309 \\
\hline Hong Kong & 95,209 & 105,173 & 110,535 & 100,810 \\
\hline Kodivoh & 22,279 & 51,327 & 110,294 & 62,691 \\
\hline Singapore & 108,899 & 115,701 & 85,946 & 81,875 \\
\hline Etc & 412,785 & 478,436 & 627,832 & 598,591 \\
\hline Total & $1,147,498$ & $1,320,495$ & $1,418,251$ & $1,201,676$ \\
\hline
\end{tabular}

(Department of Agriculture, 2009)

Table 3: Quantity and value of chemical import

\begin{tabular}{|c|c|c|c|}
\hline \multirow[b]{2}{*}{ Items } & \multicolumn{3}{|l|}{ Years } \\
\hline & 2003 & 2004 & 2005 \\
\hline \multicolumn{4}{|l|}{ Insecticide } \\
\hline Quantity (ton) & 6,239 & 7,745 & 19,080 \\
\hline Value (million baht) & 1,646 & 2,179 & 6,589 \\
\hline \multicolumn{4}{|l|}{ Fungicide } \\
\hline Quantity (ton) & 4,015 & 2,429 & 4,962 \\
\hline Value (million baht) & 627 & 579 & 914 \\
\hline \multicolumn{4}{|l|}{ Herbicide } \\
\hline Quantity (ton) & 12,946 & 8,697 & 15,662 \\
\hline Value (million baht) & 2,473 & 2,217 & 3,260 \\
\hline \multicolumn{4}{|l|}{ Other } \\
\hline Quantity (ton) & 489 & 519 & 1,189 \\
\hline Value (million baht) & 247 & 118 & 163 \\
\hline \multicolumn{4}{|l|}{ Total } \\
\hline Quantity (ton) & 23,689 & 19,390 & 40,893 \\
\hline Value (million baht) & 4,991 & 5,093 & 10,926 \\
\hline
\end{tabular}

Apart from large area of rice plantation, the northern region also the most growth of rice milling industry. Department of industrial work in 2005 reported that there are more than 29,000 rice mills are scatted in the region which is equivalent to $74.3 \%$ of the country (Limpayoonwong, 2009) Nowadays, the rice milling industry is expanding according to the increasing of exportation market.

Therefore, rice storage is very important. There are many types of enemy of rice that deteriorate quality such as Rhyzopertha dominica F., Red flour beetle, Siamese grain beetle, Angoumois Grain Moth, Rice weevil and Maize weevil (Suprakan et al., 2009; Mungpaseard et al., 2009). The main enemy of Hom
Mali Rice is Rice Weevil. It is a small insect and grows fast with small amount of food eating. Its deteriorate rice by bite both internal and external rice kernel resulting in damage and loss of rice.

In the present, there are wildly use of agriculture chemical to kill insects during rice storage because of it ease to use, simple technique and convenience. The chemicals used are imported (Rattankosum, 2009). The amount of imported chemical use in agricultural are listed in Table 3.

However, it is known that there are many possible of toxic in human and environment from using chemical. Furthermore, chemical usage is not meet export standard of organic Agriculture Certification Thailand (ATC), Good Manufacturing Practice (GMP) and Hazard Analysis and Critical Control Point (HACCP), if there is residual toxic (Insorn et al., 2009). From those problems, there are many attempts to avoid chemical using such as cleaning the storage, natural substance or controlling atmosphere (Visantanon and Nuanwat, 2005). But these methods could not totally get rid of insects. The used of infrared radiation heating in disinfestations was first reported by (Pan et al., 2007; Ramatchima, 2009). By applying heat to rice for a short period of time, insects are gradually dead. The infrared radiation is also used in drying process for agriculture products.

However, it is necessary to the study of cost in the rice disinfestations between the Infrared radiation heating application and chemical application in order to obtain information in decision making. Therefore, the aims of this research are to study economic expenses and involving cost including fixed cost and variable cost. For example, the fixed cost; rent, depreciation and house and the variable cost; paddy rice, transportation, direct labor, packaging, commission, insurance, rice mill plant fuel, maintenance and factory overhead (Vairabutr, 2009; Prasungsuk, 2009).

\section{MATERIALS AND METHODS}

- Data and information collected by surveying and interview both government and rice milling enterprises from private in Surin province. The information studied were type of insects, rice storage method, organization and business method, cost structure and exportation system

- Cost analysis in this study follows the method reported by (Noomhom et al., 2009; Raturai, 2009). Rate of return was also determined. 


\section{RESULTS}

\section{Rice mill enterprise: Surin province area:}

- The majority of the rice milling business characteristic is in the form of company co, Ltd

- From the database of the department of industrial, the listed of licensed enterprises are shown in Table 4

- The licensed enterprises were random sampling for 10 enterprises to visit and collected business data and engineering data. It was found that for the large rice mills were established for more than 25 years. The production was average 60 ton days ${ }^{-1}$. The property value was average 46,681,450 baht. Drying paddy rice was performed using dryer or sun drying. The fuel and energy used mostly was electricity

The J.P. inter rice international co.ltd was chosen as a case study. This is due to the J.P. inter rice international co.ltd is the largest rice mill in the exported only licensed enterprise.

The business process of the rice mill: The rice milling process started from buying rice paddy from Farmers, then milling rice and selling rice to consumers abroad. In this study, costs used in this study calculation were collected from cost involving only in the rice milling process in year 2008. The total cost in rice milling business can be divided into 2 types as below:

- Fixed cost such as salary and wage, house depreciation/building office and tool/equipment depreciation. Table 5 is a listed of major properties involving in rice milling business. The depreciation cost of each property was calculated from value divided by its service lift. Therefore, the depreciation cost of whole properties per year is equal to $2,875,256$ baht year ${ }^{-1}$. Salary is estimated from 7 office workers and wages are estimated from temporally workers. Therefore, total salary and wages were $2,510,000$ baht year $^{-1}$

- Variable cost such as price of paddy, transportation, packaging cost. All costs are listed in Table 6.

From Table 6, the fixed cost equal to 5,385,256 baht or $2 \%$ of total cost in year 2008 and variable cost equal to $274,922,345$ baht or $98 \%$ of total cost.
Table 4: Amount of rice milling (Surin province)

\begin{tabular}{lr}
\hline Type of licensed enterprise & Amount (unit) \\
\hline Exported only & 8 \\
Large rice mill plant $\left(>20\right.$ ton $\left.\mathrm{day}^{-1}\right)$ & 47 \\
Medium rice mill plant $\left(6-20{\left.\text { ton } \mathrm{day}^{-1}\right)}^{-1}\right.$ & 2 \\
Wholesale & 21 \\
Rice hub & 7 \\
Total & 85 \\
\hline
\end{tabular}

Table 5: The properties in rice milling business

\begin{tabular}{|c|c|c|c|}
\hline Items & $\begin{array}{l}\text { Value } \\
\text { (baht) }\end{array}$ & $\begin{array}{l}\text { Life } \\
\text { (years) }\end{array}$ & $\begin{array}{l}\text { Depreciation } \\
\text { cost = value/year } \\
\left(\text { baht years }{ }^{-1}\right)\end{array}$ \\
\hline Office/rice milling building & $18,000,000$ & 20 & 900,000 \\
\hline Rice storage building & $1,950,000$ & 20 & 97,500 \\
\hline Rice milling machines & $7,200,000$ & 15 & 480,000 \\
\hline $\begin{array}{l}\text { Humidity reduction } \\
\text { machines }\end{array}$ & $1,250,000$ & 15 & 83,333 \\
\hline Truck 6 wheels & $15,000,000$ & 15 & $1,000,000$ \\
\hline Big weight & 450,000 & 15 & 30,000 \\
\hline Small weight & 27,000 & 5 & 5,400 \\
\hline Flock lift hydraulics & 950,000 & 15 & 63,333 \\
\hline Small trolley & 3,450 & 5 & 690 \\
\hline Belt conveyor & $1,500,000$ & 10 & 150,000 \\
\hline $\begin{array}{l}\text { Humidity measurement } \\
\text { equipment }\end{array}$ & 220,000 & 5 & 44,000 \\
\hline Sack sewing machines & 52,000 & 10 & 5,200 \\
\hline $\begin{array}{l}\text { Vacuum bag packing } \\
\text { machine }\end{array}$ & 79,000 & 5 & 15,800 \\
\hline Total & $46,681,450$ & Total & $2,875,256$ \\
\hline
\end{tabular}

Table 6: Fixed cost, variable cost and total cost

\begin{tabular}{lrr}
\hline & \multicolumn{1}{l}{$\begin{array}{l}\text { Value } \\
\text { (baht year }{ }^{-1} \text { ) }\end{array}$} & Percent \\
\hline Items & & \\
Fixed cost & $2,510,000$ & \\
Salary and wages & $2,875,256$ & \\
Total property depreciation & $5,385,256$ & 2 \\
Total of fixed cost & & \\
Variable cost & $266,280,000$ & \\
Paddy (14,000 baht ton ${ }^{-1}$ ) & $3,000,000$ & \\
Transportation/fuel & $5,057,665$ & \\
Milled rice packing sacks & 45,000 & \\
Cord & 57,505 & \\
Interest & 12,567 & \\
Telephone bill & 429,358 & \\
Milling rice energy and water bill & 24,500 & \\
Maintenance & 15,750 & \\
Factory overhead & $274,922,345$ & 98 \\
Total of variable cost & $280,307,601$ & 100 \\
Total cost & 19,020 & \\
The total paddy quantity (ton year ${ }^{-1}$ ) & $14,737,51$ & \\
Average cost /1 ton of paddy & & \\
\hline
\end{tabular}

\section{DISCUSSION}

Calculate of the capital rate of return in rice milling business:

The capital rate of return: The rate of return for rice milling business come from products sale as shown in Table 7 and 8 such as milled rice sale, broken rice sale, bran sale and hush sale polish and husk. 
Energy Rec. J. 1 (2): 152-157, 2010

Therefore, income that rises from milled rice sale was approximately $284,349,000$ baht $(82.93 \%$ of total income) and big rice broken sale was approximately $30,812,400$ baht or $8.99 \%$ of total income (Table 8).

The cost comparisons rice disinfestations between infrared radiation heating application and chemical application (Table 9-12):

- The infrared radiation machine would be applied after milled rice before packaging. The infrared radiation machine would be $200 \times 300 \times 250 \mathrm{~cm}$ in size and it will operate at $60^{\circ} \mathrm{C}$ for $60 \mathrm{sec}(1 \mathrm{~min})$ as demonstrated by (Pan et al., 2007).

The rice milling are productivity average 60 ton day $^{-1}$ or $60 \times 317$ days equal to 19,020 ton year $^{-1}$ $\left(19,020,000 \mathrm{~kg}\right.$ year $\left.^{-1}\right)$. The operation of infrared machine would be done in a tray with $50 \times 100 \mathrm{~cm}$ with one layer of rice. Therefore, in one operation $(1 \mathrm{~min})$ can process 25 or $1,500 \mathrm{~kg}$ of rice in $1 \mathrm{~h}$ or 12 ton day $^{-1}$ machine ${ }^{-1}$. The optimal is 5 machines to support rice of 60 ton day ${ }^{-1}$ :

$$
\begin{aligned}
\text { Fixed cost } / \text { unit } & =\frac{\text { Fixedcost }}{\text { Products amount year }}{ }^{-1} \\
& =75,340 / 19,020,000 \\
& =0.0039 \mathrm{baht} \mathrm{kg}^{-1}
\end{aligned}
$$

$$
\begin{aligned}
\text { Variable cost / unit } & =\frac{\text { Variable cost }}{\text { Products amount year }}{ }^{-1} \\
& =5,815,957 / 19,020,000 \\
& =0.3057 \mathrm{baht} \mathrm{kg}^{-1}
\end{aligned}
$$

Total cost $/$ unit $=$ Fixedcost $/$ unit + variable cost $/$ unit

\begin{tabular}{|c|c|c|c|c|}
\hline Items & $\begin{array}{l}\text { Sale quantity } \\
(\mathrm{kg})\end{array}$ & $\begin{array}{l}\text { Sale price } \\
\text { (baht) }\end{array}$ & $\begin{array}{l}\text { Money } \\
\text { total (baht) }\end{array}$ & Percent \\
\hline Mille & $12,363,000$ & 23.0 & $284,349,000$ & 82.93 \\
\hline le & & & & 8.99 \\
\hline & & 13 & 000 & 4.33 \\
\hline oug & 760,800 & 2. & 1,600 & 0.44 \\
\hline ice & 95 & 8. & $7,608,000$ & 2.22 \\
\hline Husk sale & $2,092,200$ & 1.8 & $3,765,960$ & 1.09 \\
\hline Total & $19,020,000$ & & $342,892,560$ & 100.00 \\
\hline
\end{tabular}

$$
\begin{aligned}
& =0.0039+0.3057 \\
& =0.3096 \text { baht kg }
\end{aligned}
$$

Table 7: The rate of return of rice milling from paddy $1,000 \mathrm{~kg}$

\begin{tabular}{|c|c|c|c|c|c|}
\hline Items & Amount (unit) & Cost per unit (baht) & Capital money (baht unit ${ }^{-1}$ ) & Application time (year) & Cost (baht year $\left.{ }^{-1}\right)$ \\
\hline Infrared radiation machine & 5 & 65,000 & 325,000 & 5 & 65,000 \\
\hline Sack sewing machine & 3 & 17,333 & \multirow[t]{2}{*}{51,999} & \multirow{2}{*}{5} & 10,340 \\
\hline Total & & & & & 75,340 \\
\hline \multicolumn{6}{|c|}{ Table 10: The variable cost of infrared radiation application } \\
\hline \multicolumn{2}{|l|}{ Items } & & Amount and unit & Price (baht unit ${ }^{-1}$ ) & Total (baht year ${ }^{-1}$ ) \\
\hline \multicolumn{3}{|c|}{$\begin{array}{l}\text { Wage of an operator of infrared radiation machine } \\
\left(5 \times 151 \times 317=239,335 \text { baht } \text { year }^{-1}\right)\end{array}$} & 5 person & 151 (baht day ${ }^{-1}$ ) & 239,335 \\
\hline \multicolumn{2}{|c|}{$\begin{array}{l}\text { Wage of an operator of sack sewing machine } \\
\left(3 \times 151 \times 317=143,601 \text { baht }^{-1}{ }^{-1}\right)\end{array}$} & & 3 persons & 151 (baht day ${ }^{-1}$ ) & 143,601 \\
\hline \multicolumn{2}{|c|}{ Electricity of Infrared radiation machine } & & 5 machine & $155.75(5 \times 155.75 \times 12)$ & 9,345 \\
\hline \multicolumn{2}{|c|}{ Electricity of sack sewed machine } & & 3 machine & $236.41(3 \times 236.41 \times 12)$ & 8,511 \\
\hline \multicolumn{2}{|c|}{ Amount of rice sack; size $101 \mathrm{~kg}$} & & 23,168 pieces & 45 baht & $1,042,560$ \\
\hline \multicolumn{2}{|l|}{ PE plastic sack; size 49 kg } & & 27,347 pieces & 15 baht & 410,205 \\
\hline \multicolumn{2}{|l|}{ Jumbo sack; size $1,000 \mathrm{~kg}$} & & 15,340 pieces & 235 baht & $3,604,900$ \\
\hline \multicolumn{2}{|l|}{ Cord } & & 550 rolls & 650 & 357,500 \\
\hline \multicolumn{5}{|l|}{ Total } & $5,815,957$ \\
\hline Items & Amount (unit) & Cost per unit (baht) Cap & ital money (baht unit ${ }^{-1}$ ) & Application age (year) & Cost (baht year ${ }^{-1}$ ) \\
\hline $\begin{array}{l}\text { Sack sewing machine } \\
\text { Total }\end{array}$ & 317,333 & 51,999 & 5 & 10,340 & 10,340 \\
\hline
\end{tabular}

\begin{tabular}{lccrr}
\hline Items & $\begin{array}{l}\text { Sale } \\
\text { quantity } \\
(\mathrm{kg})\end{array}$ & $\begin{array}{l}\text { Sale } \\
\text { price } \\
(\text { Baht })\end{array}$ & $\begin{array}{l}\text { Money } \\
\text { total } \\
\text { (Baht) }\end{array}$ & Percent \\
\hline Milled rice sale & 650 & 23.0 & 14,950 & 82.93 \\
Big rice broken sale & 90 & 18.0 & 1,620 & 8.99 \\
Small rice broken sale & 60 & 13.0 & 780 & 4.33 \\
Rough rice bran sale & 40 & 2.0 & 80 & 0.44 \\
Fine rice bran sale & 50 & 8.0 & 400 & 2.22 \\
Husk sale & 110 & 1.8 & 198 & 1.09 \\
Total & 1,000 & & 18,028 & 100.00 \\
\hline
\end{tabular}

Table 8: The rate of return of rice milling from paddy $19,020,000 \mathrm{~kg}$, $\left(60 \times 317\right.$ days $=19,020$ ton years $\left.{ }^{-1}\right)$

Note: Sale price average $\mathrm{kg}^{-1}$ (rice sale price/amount of output) 18.028 baht kg $^{-1}$

Table 9: The fixed cost of infrared radiation heating application 
Energy Rec. J. 1 (2): 152-157, 2010

Table 12: Variable cost of chemical application

\begin{tabular}{|c|c|c|c|}
\hline Items & Amount (unit) & Price (baht unit ${ }^{-1}$ ) & Total $\left(\right.$ bahtyear $\left.^{-1}\right)$ \\
\hline $\begin{array}{l}\text { Wage of an operator of sack sewing machine } \\
\left(3 \times 151 \times 317=143,601 \text { baht year }^{-1}\right)\end{array}$ & 3 persons & 151 (baht day ${ }^{-1}$ ) & 143,601 \\
\hline Electricity of sack sewed machine & 3 machines & $236.41(3 \times 236.41 \times 12)$ & 8,511 \\
\hline Amount of rice sack; size $101 \mathrm{~kg}$ & 23,168 pieces & 45 baht & $1,042,560$ \\
\hline PE plastic sack; size $49 \mathrm{~kg}$ & 27,347 pieces & 15 baht & 410,205 \\
\hline Jumbo sack; size $1,000 \mathrm{~kg}$ & 15,340 pieces & 235 baht & $3,604,900$ \\
\hline Cord & 550 rolls & 650 & 357,500 \\
\hline Chemical ( 1 ton 10.50 baht $\left.^{-1}\right)$ & 19,020 ton & 10.5 & 199,710 \\
\hline Total & & & $5,766,987$ \\
\hline
\end{tabular}

The cost comparisons of chemical application:

$$
\begin{aligned}
\text { Fixed cost unit }^{-1} & =\frac{\text { Fixed cost }}{\text { Products amount year }}{ }^{-1} \\
& =10,340 / 19,020,000 \\
& =0.0005 \text { baht kg }
\end{aligned}
$$

$$
\begin{aligned}
\text { Variable cost / unit } & =\frac{\text { Variable cost }}{\text { Products amount year }}{ }^{-1} \\
& =5,766,987 / 19,020,000 \\
& =0.3032 \mathrm{baht} \mathrm{kg}^{-1}
\end{aligned}
$$

Total cost $/$ unit $=$ Fixed cost $/$ unit + variable cost $/$ unit

$$
\begin{aligned}
& =0.0005+0.3032 \\
& =0.3037 \mathrm{baht} \mathrm{kg}{ }^{-1}
\end{aligned}
$$

\section{CONCLUSION}

Major enemy of Hom Mali Rice during stock is rice weevil. The rice deteriorations caused by rice weevil such as dirty rice, powder dust, weight loss and bad taste. The economic expenses and involving cost in applying radiation heating and chemical were calculated and compared. The necessary information were collected from the J.P. Inter rice International co. Ltd., the largest export rice mill in Surin province.

The cost structure of rice milling business consist of 2 groups include fixed cost equal to 5,385,256 baht (2\% of total cost) and variable cost equal to $274,922,345$ baht (98\% of total cost).

The rate of return in rice milling was 19,020 ton year $^{-1}$. The income from rice sale was approximately $284,349,000$ baht year $^{-1}$ (82.93\% of total income) and from broken rice sale was approximately $30,812,400$ baht ( $8.99 \%$ of total income). The total cost of using infrared radiation heating application and chemical application equal to 0.3096 and 0.3037 bath $\mathrm{kg}^{-1}$, respectively. Therefore, the infrared method increase total cost by $1 \%$ or cost reduction of 112,218 baht year ${ }^{-1}$.

\section{ACKNOWLEDGEMENT}

Author would like to thank Department of Industrial Engineering, Faculty Engineering, Ubonratchani University and rice mill enterprise in Surin province.

\section{REFERENCES}

Buanuan, W., 2009. Development of key performance indicators of logistics process for Hom mali rice exporting mill in roi-et province: ThaiLIS is Thailand library integrated system. http://tdc.thailis.or.th/tdc/search_result.php

Department of Agriculture, 2009. Hom Mali Rice exports.

http://www.afet.or.th/v081/thai/product/bhmr/statis tic_export.php

Insorn, W. et al., 2009. Articles of academic. Department of Industrial Engineering, Faculty of Engineering Ubonrachathani University. http://www.eng.ubu.ac.th/ ie/article/article_public ation.htm

Limpayoonwong, B., 2009. Rice Mills Business. http://www.thairegistration.com/mainsite/fileadmin /statistic/statistic_bycategory/0028/1_20090908.pdf

Mungpaseard, N. et al., 2009. Insects of rice enemy. http://www.brrd.in.th/rkb/data_005/rice_xx205_bug_index.html

Noomhom, A. et al., 2009. The development and improvement of fumigation technology controlled atmosphere and irradiation to disinfestations in packed rice: The Thailand Research Fund Regional Office.

http://www.vijai.org/research/default.asp?group=\& page $=50$

Pan, Z., R. Khir, L.D. Godfrey, R. Lewis, J.F. Thompson and A. Salim, 2007. Feasibility of simultaneous rough rice drying and disinfestations by infrared radiation heating and rice milling quality. Food Eng., $\quad 84$ : $\quad 469-479 . \quad$ DOI: 10.1016/j.jfoodeng.2007.06.005 
Prasungsuk, S., 2009. A study of marketing structure efficiency of processing and brake-even point of the Klong Luang agricultural cooperative limited rice mill Pratumtanee province: ThaiLIS is Thailand Library Integrated System. http://tdc.thailis.or.th/tdc/search_result.php

Rattankosum, C., 2009. Financial cost benefit analysis of natural chemical project (Neem extract): ThaiLIS is Thailand Library Integrated System. http://tdc.thailis.or.th/tdc/search_result.php

Raturai, O., 2009. An analysis of cost and yield of investment in Rice Mills: A case study of large Rice Mills in Lop Buri: ThaiLIS is Thailand Library Integrated System. http://tdc.thailis.or.th/tdc/search_result.php

Ramatchima, P., 2009. A study on elimination of paddy insect by infrared radiation: ThaiLIS is Thailand Library Integrated System. http://tdc.thailis.or.th/tdc/search_result.php
Suprakan, C. et al., 2009. Study on stored grain in airtight storage in Thailand. http://pikul.lib.ku.ac.th/cgibin/agdb1.exe?rec_id=060525\&database $=$ agdb1\&s earch_type $=$ link \& table $=$ mona \&back_path=/agdb1/ mona\&lang=thai\&format_name=TFMON

Vairabutr, A., 2009. A study on paddy marketing and marketing activities of rice mills in the North Eastern region: ThaiLIS is Thailand Library Integrated System. http://tdc.thailis.or.th/tdc/search_result.php

Visantanon, P. and K. Nuanwat, 2005. Paddy Enemy Insect and Eradicate Protection. 2nd Edn., Odian Store, ISBN: 974-436-480-7, pp: 1-20. 